\section{E A Institute of \\ YK Business Administration \\ 光下 \\ Karachi \\ Leadership and Ideas for Tomorrow}

\section{Business Review}

Volume 8 Issue 1 January-June 2013

$1-1-2013$

\title{
Back Matter of Volume 8 Number 1
}

Tufail A. Qureshi

Institute of Business Administration, Karachi

Follow this and additional works at: https://ir.iba.edu.pk/businessreview

Part of the Business Commons

(c) (i)

This work is licensed under a Creative Commons Attribution 4.0 International License.

\section{Recommended Citation}

Qureshi, T. A. (2013). Back Matter of Volume 8 Number 1. Business Review, 8(1), 160. Retrieved from https://doi.org/10.54784/1990-6587.1223 
https://ir.iba.edu.pk/businessreview/vol8/iss1/12

DOI: https://doi.org/10.54784/1990-6587.1223

Business Review - Volume 8 Number 1

January - June 2013

\section{BLANK PAGE}




\section{IBA \\ 掞K \\ BUSINESS REVIEW \\ Research Journal \\ of \\ The Institute of Business Administration \\ Karachi, Pakistan}

\section{Guidelines for Contributors}

Business Review is a biannual publication of the Institute of Business Administration, Karachi, Pakistan. It is a multidisciplinary journal covering a wide range of issues in the areas of business, social and management sciences, administration and governance, mathematics and computer studies, finance, economics, psychology, business ethics, logic, history of ideas, and philosophy of comparative religion.

\section{Guidelines for Authors}

1. Business Review invites the following types of contributions:

- Research papers

- Case studies and discussion papers

- Articles / Book Reviews

- Brief reports and comments

2. Manuscript should be submitted to the Editor, Business Review, Institute of Business Administration, University Road, Karachi, Pakistan.

3. Three copies of the manuscript should be submitted.

4. The text should be double spaced, on one side of the quarto paper allowing wide margins for referee's comments.

5. All illustrations, tables, etc., should be placed on separate sheets, included with each copy. Their placement should be indicated in the text.

6. Footnotes should be numbered consecutively through the text.

7. The first page of the manuscript should contain the following information. (i) title of the paper; (ii) the names(s) and institute affiliation(s) of the author(s); (iii) a footnote should give the name, postal address,telephone and fax number, and an email address of the authors.

8. The second page must contain the title, and abstract not exceeding 300 words, a maximum of 5 key words or phrases and appropriate JEL codes to be used for indexing purpose. The text will start on page number 3 .

9. Acknowledgements of all sorts should be included on the first page.

10. All mathematical derivations should be presented on a separate sheet, (not to be published) to help the referees.

11. Manuscript should include only those references that are cited in the text. Authors are advised to follow American Psychological Association (APA) style of referencing.

12. All literary material, including books, journals and manuscripts for review should be submitted in triplicate to the Editor, Business Review, Institute of Business Administration, University Road, Karachi, Pakistan.

13. It is assumed that the paper submitted is an original unpublished work and it has not already been published or submitted for publication elsewhere.

14. The opinions, ideas and evaluations expressed in the articles printed in the Business Review do not necessarily represent the views or policies of The Institute of Business Administration or the Editorial Board. They should be considered as representative example of opinions and analysis now current in the academic field on various subjects of intellectual, educational and cultural interest.

15. After internal evaluation, the Editor will send the selected articles to the external referees or the consulting foreign editors for their evaluation. Selection of the referees will be the discretion of the Editor.

16. The articles will be evaluated through anonymous peer reviews. Papers will normally be scrutinized and commented on by at least two independent expert referees in addition to the Editor.The referees will not be made aware of the identity of the author. All information about authorship will be removed from the papers.

17. The text of this publication or any part thereof may not be reproduced in any form or manner whatsoever without the permission in writing from the editor.

For advance electronic submission of the material:

businessreview@iba.edu.pk

tufail.qureshi@gmail.com

tqureshi@iba.edu.pk

All enquiries should be addressed to the Editor, Business Review, Research Journal of The Institute of Business Administration, Karachi, Pakistan. 
https://ir.iba.edu.pk/businessreview/vol8/iss1/12

DOI: https://doi.org/10.54784/1990-6587.1223

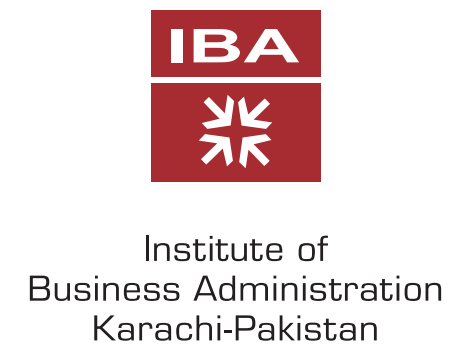

Main Campus: University Road, Karachi. Tel: (92-21) 38104700 Fax: (92-21) 99261508

City Campus: Garden/Kiyani Shaheed Road, Karachi.

Website: www.lba.edu.pk Email: tqureshi@iba.edu.pk 